\title{
A HIGH TEMPERATURE STUDY OF TRIPHILITE
}

\author{
SÉRGIO DEGANELLO*
}

\begin{abstract}
Two samples of triphilite were studied at high temperature with a Guinier-Lennè camera. Triphilite $1(\mathrm{Mn} / \mathrm{Fe}+\mathrm{Mn} \simeq 0.22)$ exhibits an ordered diffraction pattern up to $780^{\circ} \mathrm{C}$ under strictly reducing conditions $\left(\mathrm{N}_{2}\right.$ gas). Triphilite $2(\mathrm{Mn} / \mathrm{Fe}+\mathrm{Mn} \approx 0.24)$, upon oxidation, shows drastic changes in the value of the intensities of the 2.54 and $2.47 \AA$ diffraction lines. These at $22^{\circ} \mathrm{C}$ exhibit values which are approximately the reverse than at $550^{\circ} \mathrm{C}$. The strong disturbances affecting the $\mathrm{M}(2)$ site as a consequence of the process of oxidation and of the temperature changes suggest that it is not unlikely that triphilites, representative of conditions of high entropy and rapid crystalization, could be disordered.
\end{abstract}

RESUMO Duas amostras de trifilita foram estudadas a altas temperaturas com uma camara Guinier-Lennè. A trifilita $1(\mathrm{Mn} / \mathrm{Fe}+\mathrm{Mn} \simeq 0,22)$ exibe um padrão de difração ordenado até $780^{\circ} \mathrm{C}$, sob condiçóes estritamente redutoras (gás $\mathrm{N}_{2}$ ). A trifilita $2(\mathrm{Mn} / \mathrm{Fe}+\mathrm{Mn} \simeq 0,24)$, uma vez oxidada, mostra mudanças drásticas no valor das intensidades das linhas de difração de $2,54 \AA$ e $2,47 \AA$, as quais, à temperatura de $22^{\circ} \mathrm{C}$, exibem valores que são aproximadamente o inverso daqueles a $550^{\circ} \mathrm{C}$. As fortes perturbações que afetam a posição $\mathrm{M}(2)$, como conseqüencia do processo de oxidação e das mudanças de temperatura, sugerem que é razoável supor que as trifilitas representativas de condiçóes de entropia elevada e cristalização rápida possam exibir um retículo desordenado.

INTRODUCTION Progressive substitution of $\mathrm{Fe}^{+2}$ and $\mathrm{Mn}^{+2}$ in the formula $\mathrm{Li} \mathrm{Fe}_{1-x}^{+2}$ $\mathrm{Mn}_{x}^{+2} \mathrm{PO}_{4}$ (1) results in a variety of phases constituting a solid solution whose end members are triphilite and lithiophilite (respectively $\mathrm{LiFePO}_{4}$ and $\mathrm{LiMnPO}_{4}$ ). Partial oxidation of (1) results in sicklerite $\left(\mathrm{Li}_{x} \mathrm{Fe}_{1-x}^{+3} \mathrm{Mn}^{+2} \mathrm{PO}_{4}\right)$ which, upon removal of $\mathrm{Li}$ and exchange of $\mathrm{Mn}^{+2}$ to $\mathrm{Mn}^{+3}$, converts to heterosite $\left(\mathrm{Fe}_{1-x}^{+3} \mathrm{Mn}_{x}^{+3} \mathrm{PO}_{4}\right)$. While this paragenesis is commonly accepted, no evidence has been reported regarding the thermal behavior of triphilites characterized by different cationic stoichiometries and degrees of oxidation. Such an information, aside from its academic interest, would prove particularly useful in the interpretation of the paragenesis of associations of the primary phosfates, particularly in relation to exolution phenomena. The point has been stressed by Moore (1972) in an introductory discussion of the problem.

Here we have focused our attention on two triphilites exhibiting slightly different $\mathrm{Mn} / \mathrm{Fe}+\mathrm{Mn}$ ratios and studied them at different temperature, under reducing and slightly oxidizing conditions. Interpretation of the high temperature powder data was facilited by a structural refinement of a sample of triphilite by Finger et al (1970).

Triphilite 1 SINGLE CRYSTAL WORK Zero level photographs of a sample characterized by $\mathrm{Mn} / \mathrm{Fe}+\mathrm{Mn} \simeq 0.22$ exhibited a very sharp diffraction pattern lacking any evidence of streaking or diffuseness. Although the study was not carried out with strictly monochromated radiation, limitation which precludes a quantitative approach to a study of the crystal dynamics of the lattice, such a lack of planar and intraplanar disturbances suggests absence of structural defects. Furthermore it excludes significant contribution to scattering from thermal vibration of the atomic planes.

*Departamento de Geociências, Universidade de Brasília, Brasília, 70.000, DF 
POWDER WORK Experiments have been carried out at $25^{\circ}, 100^{\circ}, 220^{\circ}, 340^{\circ}, 550^{\circ}$, $650^{\circ}, 780^{\circ}, 850^{\circ}$ and $900^{\circ} \mathrm{C}^{*}$ with a Guinier-Lennè camera connected to a system capable of erogating $\mathrm{N}_{2}$ gas at different pressure. The hot $\mathrm{N}_{2}$ coming from the X-ray chamber was collected into a container via a line sealed to the gas outlet. This system was devised in order to prevent oxidation of $\mathrm{Fe}^{+2}$ and $\mathrm{Mn}^{+2}$. Prior to the commencement of each run, $\mathrm{N}_{2}$ gas was flushed into the specimen-chamber for about $2 \mathrm{hrs}$. and then allowed to flow in the system for the entire duration of each experiment. The samples were mounted on a platinum grid, the diffraction lines of which were used to check the temperature readings obtained from a recorder potentiometer operated in continuous mode. This was possible since the coefficients of thermal expansion of $\mathrm{Pt}$ are quite accurately known (Campbell, 1968).

Upon heating, the relative intensities of the diffracta uniformly decrease in agreement with theoretical considerations. No other change is noticed up to $780^{\circ} \mathrm{C}$, temperature at which two weak diffraction lines $(\mathrm{d}=4.11$ and $2.71 \AA$, respectively) appear. Further temperature increments result in a better resolution of the "new" diffracta at the expenses of the basic pattern which is very little evidenced (Fig. 1). Three additional independent runs were carried out with fresh material in order to test the reproducibility of the results and try to improve the quality of the diffraction pattern in the temperature range $780^{\circ}$ $-900^{\circ} \mathrm{C}$. While reproducibility of the results was obtained in all instances, the relative intensities of the diffracta at a temperature above $800{ }^{\circ} \mathrm{C}$ were consistently too weak for any meaningful study. After slow cooling of the specimen to room temperature under a constant flow of $\mathrm{N}_{2}$ gas, a microscopic examination was carried out. This did not show any trace of oxidation of the sample.

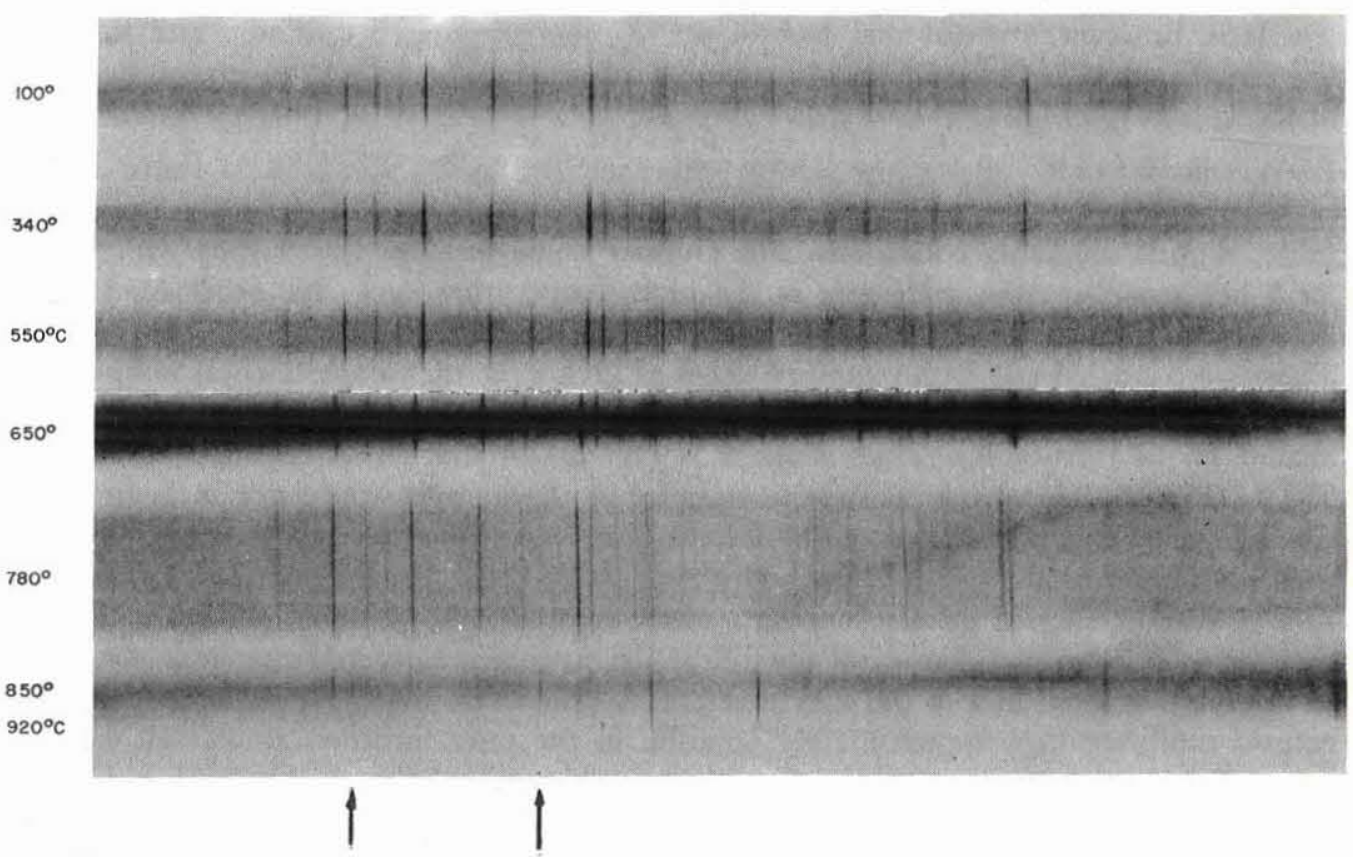

Figura 1 - Triphilite 1 . Notice the stability of the sample to the phononic disturbance and the two extra diffraction lines at $\mathrm{d}=4.11$ and $2.71 \AA$. These are indicated by arrows

*Estimated accuracy of temperature readings for the powder work reported in this paper: $\pm 8^{\circ} \mathrm{C}$ 
Triphilite 2 SINGLE CRYSTAL WORK Upon examination with the precession camera ( $\mathrm{hkO}$ and $\mathrm{Okl}$ levels), a sample of triphilite characterized by $\mathrm{Mn} / \mathrm{Fe}+\mathrm{Mn}=0.24$ did not exhibit significant changes in the diffraction pattern at 22 and $550^{\circ} \mathrm{C}^{*}$, aside from the expected decrease in the value of the relative intensities. No immediate evidence of temperature - induced diffuseness that could be related either to disorder or to strong contributions of thermal diffuse scattering was recorded. These observations might be considered in terms of the results of a three-dimensional refinement of a sample of triphilite by Finger et al. (1970). According to these authors the structure is well ordered at room temperature and isotypic with monticellite (Table I).

Table I - Atomic parameters of triphilite

\begin{tabular}{lllll}
\hline *Atom & \multicolumn{1}{c}{$x$} & \multicolumn{1}{c}{$y$} & \multicolumn{1}{c}{$z$} \\
\hline $\mathrm{M}(1)$ & 0 & 0 & 0 & \\
$\mathrm{M}(2)$ & 0.989 & 0.277 & 0.25 & $* * \mathrm{a}=4.7031(3) \AA$ \\
$\mathrm{Si}$ & 0.427 & 0.094 & 0.25 & $\mathrm{~b}=10.3586(9) \AA$ \\
$0(1)$ & 0.766 & 0.092 & 0.25 & $\mathrm{c}=6.0285(6) \AA$ \\
$0(2)$ & 0.220 & 0.448 & 0.25 & \\
$0(3)$ & 0.278 & 0.163 & 0.034 & \\
\hline
\end{tabular}

*The values of the atomic coordinates are form Birle et al. (1968)

**The cell originally given by Finger et al. (1970) has been transformed from Pmnb according to an orientation compatible with Pbnm

It is, however, stressed that lack of use of monochromated radiation and the short wavelenght used (Zr filtered Mok $\alpha$ ) precluded a constructive study of the crystal dynamics of the lattice.

POWDER WORK Being the sample characterized by an almost total statistical distribution of the $\mathrm{Fe}^{+2}$ over $\mathrm{Fe}^{+3 * *}$, it was decided to carry out a high temperature study under slightly oxidizing conditions. The Guinier-Lennè camera was flushed with $\mathrm{N}_{2}$ gas for 2 hrs. prior to commencement of the high temperature cycle. No other $\mathrm{N}_{2}$ gas was flushed into the system for the entire duration of all the subsequent high temperature runs. These were carried out with exposure times of 12 hrs. at each experimental temperature $\left(22^{\circ}, 100^{\circ}, 183^{\circ}, 247^{\circ}, 326^{\circ}, 390^{\circ}, 440^{\circ}, 483^{\circ}, 550^{\circ} \mathrm{C}\right)$. Since, among the other ones, a drastic change in the relative intensities of the 2.54 and $2.47 \AA$ diffraction lines was recorded at $550^{\circ} \mathrm{C}$ (Fig. 2), the sample was let to stabilize at this temperature prior to beginning a cooling cycle. This was carried out by lowering the experimental temperature sequentially through the same values used in the high temperature cycle. In all instances a stabilization time of 2 hours elapsed prior to exposure of the sample to X-rays (12 hours). Fig. 3 shows that the most interesting feature of the diffraction pattern is a gradual change in the values of the relative intensities of the 2.47 and $2.54 \AA$ diffraction lines. These, at room temperature, exhibit values approximately opposite to the ones recorded at $550^{\circ} \mathrm{C}$.

A final microscopic examination of the sample revealed the presence of a red patina which was interpreted as a product of oxidation. This observation clarifies the uneven

*This study was carried out with a sepertine gas heater using $\mathrm{N}_{2}$ gas, according to a technique briefly outlined elsewhere (Deganello, 1972)

**This analysis was kindly carried out by Prof. S. Hafner using techniques of Mössbauer spectroscopy 


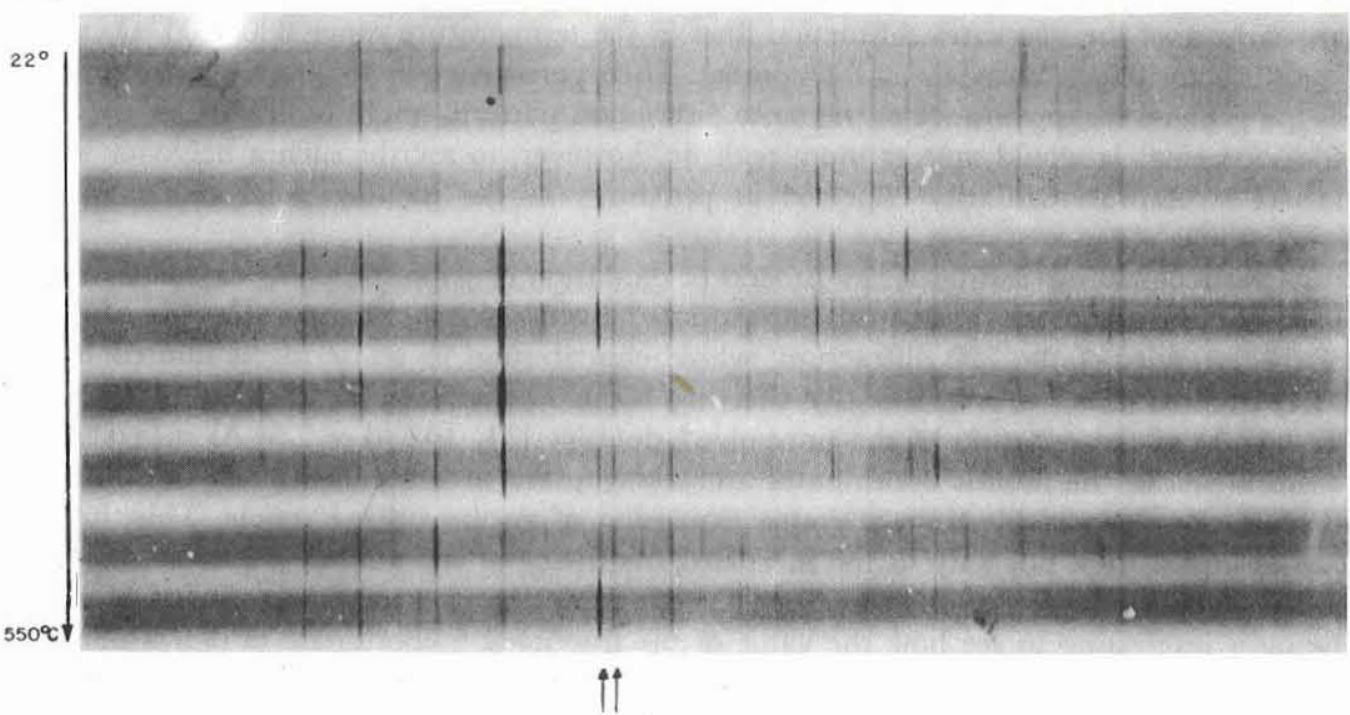

Figura 2 - Triphilite 2. Heating cycle. Notice the uneven temperature dependence of the relative intensities of the diffraction lines upon oxidation and increasing temperature. Arrows indicate position of the 2.54 and $2.47 \AA$ diffraction lines, respectively

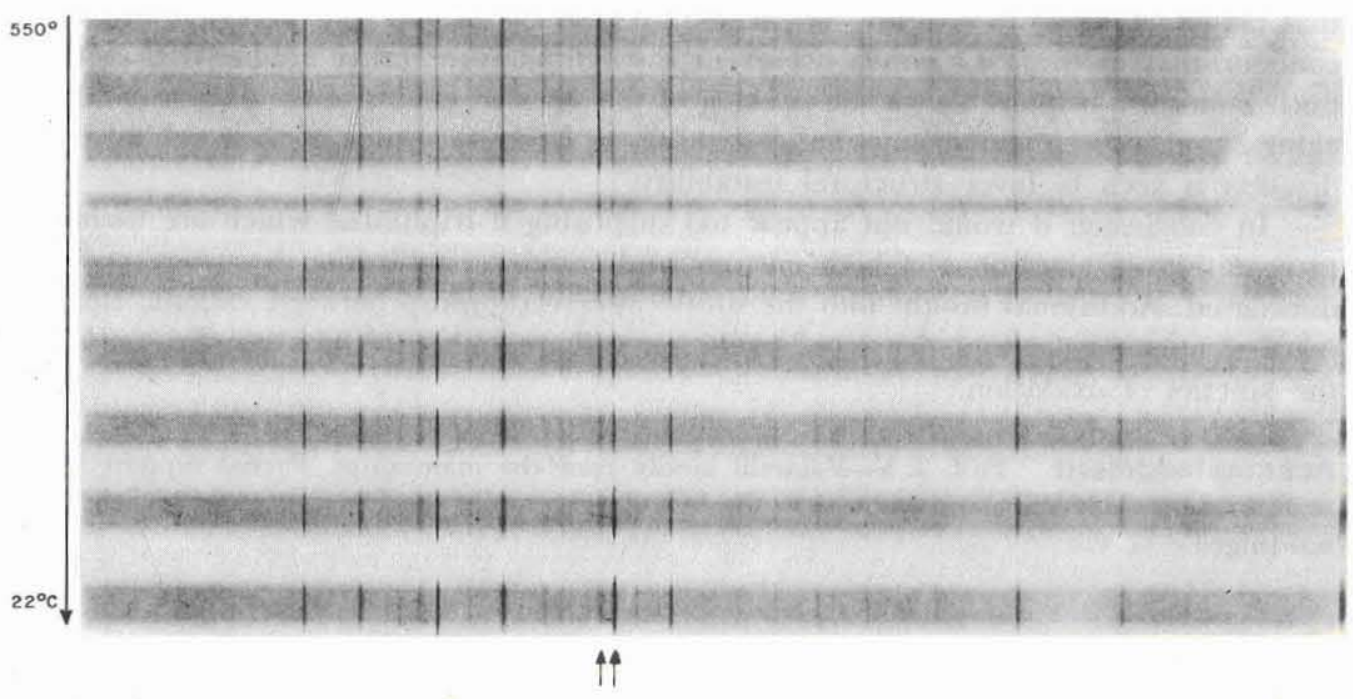

Figura 3 - Triphilite 3 . Cooling cycle. Notice the intensity change affecting the 2.54 and $2.47 \AA$ diffraction lines. These are indicated by arrows

thermal behavior of the relative intensities of the diffraction pattern recorded during the preliminary heating cycle (Fig. 2).

DISCUSSION OF RESULTS Triphilite 1 is remarkably stable to phononic disturbances. Although powder patterns are much too insensitive for tackling the problem of order-disorder in a structural array, it is evident (Fig. 1) that neither a process of long range order nor any evidence of an incoming phase transition is recorded up to $780^{\circ} \mathrm{C}$. The 
appearance of the two extra diffraction lines in the temperature range $800^{\circ}-900^{\circ} \mathrm{C}$ cannot be satisfactorily accounted for in this context. Their persistency up to $900^{\circ} \mathrm{C}$, concomitantly to the gradual disappearance of the basic diffraction pattern, might indicate that triphilite is disordering. It would appear more realistic, however, to ascribe such a behavior to the loss of structural regularity expected in proximity of the melting point of the sample $\left(\simeq 950^{\circ} \mathrm{C}\right)$.

Particularly interesting is the process of oxidation of triphilite 2. As expected on the basis of its chemical formula and substantiated by the regular temperature dependence of the intensity of the 222 diffractum, whose contribution to scattering is limited to the $\mathrm{M}(1)$ site, oxidation is preferentially affecting $\mathrm{M}(2)$. The increase in intensity of $112(\mathrm{~d} \simeq$ $\simeq 2.47 \AA)$ at the expenses of the unresolved doublet $131,102(\mathrm{~d}=2.54 \AA)$ suggests that adjustments in the atomic coordinates are taking place in a manner much more drastir. than the one expectable from a simple expansion of an unoxidized reticle. This, in fact, has to adjust itself not only to the increased frequency of the atomic vibration but, also, to the overall charge unbalance caused by the oxidation process. Consequently it would be most interesting to see how the value of the fractional $\frac{z}{c}$ coordinate of $0(3)$ is affected, being this the only coordinated anion free of symmetry constrains along this direction. As shown in Fig. 2 the shift in intensity between 131, 102, and 112 is not an abrupt one but takes place as a function of the experimental temperature. In particular, the approximately equivalent intensity of the two diffracta at $326^{\circ} \mathrm{C}$ indicates that at this temperature sufficient activation energy has been reached to start promoving significant changes in $M(2)$. However, the reversibility of the process of the reported intensity shift excludes that major changes are affecting the structural framework and that breakage of the $\mathrm{sp}^{3}$ configuration of the $\mathrm{P}-\mathrm{O}$ bonds occurs in the temperature range studied $\left(22^{\circ}-550^{\circ} \mathrm{C}\right)$. Such bonds are responsible for the packing of the serrated chains of the oxigen octahedra along $c$ and, consequently, any change tending to lower the value of their orbital hybridization is keen to favor structural instability.

In conclusion it would not appear too surprising if triphilites, which are frozen representatives of conditions of high entropy and rapid crystallization hystories, could be disordered. Additional insight into the subtle interrelationship between cationic stoichiometries, temperature and degree of oxidation will undoubtedly be given by a study of the kinetics of oxidation.

Acknowledgment Prof. J. V. Valarelli kindly read the manuscript. Partial support to this work from the USPHS grant awarded to the SCOR program of the University of Chicago is ack: nowledged.

\section{REFERENCES}

BIRLE, J. D., GIBBS, G. V., MOORE, P. B., and SMITH, J. V. - 1968 - Crystal structures of natural olivines, Amer. Mineral. 53: 807-824

CAMPBELL, W.J. - 1962 - Platinum expansion values for thermal calibration of high temperature X-ray diffraction cameras and diffractometers, U.S. Bureau of Mines, Information Circular n. ${ }^{\circ} 8107$

DEGANELLO, S. - 1972 - A high-temperature modification of Gamma $\mathrm{Na}_{2} \mathrm{BeF}_{4}$, Jour. Amer. Ceramic Soc., 55: 584

FINGER, L. W. and RAPP, G. R. - 1970 - Refinement of the crystal structure of triphilite, Carnegie Inst., Wash. Year Book 1968-9, pp. 290-292

MOORE, P.A. - 1972 - Sarcopside: its atomic arrangement, Am. Mineralogist, 57: 24-35 